\title{
Influence of Tellurium on microstructure, mechanical and corrosion properties of Al-Zn-Mg alloys
}

\author{
Mahmoud Abbas ${ }^{1}$, M.M. Sadawy ${ }^{2}$, A.M. Hosny ${ }^{3 *}$ \\ ${ }^{1}$ Suez University, P.O. Box 43533, Faculty of Petroleum and Mining Engineering \\ Metallurgical and Material Engineering Dep. Assalam City, Suez, Egypt \\ ${ }^{2}$ Al-Azhar University, Faculty of Engineering, Mining and Pet. Dept., Nasr \\ City, P.O. Box 11371, Cairo, Egypt \\ ${ }^{3}$ Suez University, P.O. Box 43533, Faculty of Petroleum and Mining Engineering \\ 'Email: prof_abbas@hotmail.com, ${ }^{2} E m a i l:$ mosaadsadawy@yahoo.com, ${ }^{3}$ Email: \\ engamh3ma@yahoo.com
}

\begin{abstract}
In the present paper, the microstructure, mechanical and corrosion properties of Al-Zn-Mg alloys containing different contents of tellurium have been investigated. Optical microscopy, SEM/EDX, hardness and different electrochemical techniques have been utilized. The outcomes showed that additions of Te to the alloy, refined the grains and offered improvements in corrosion resistance and the mechanical properties of $\mathrm{Al}-\mathrm{Zn}-\mathrm{Mg}$ alloys. The grain size decreased from 17.11 to $78.09 \mu \mathrm{m}$, while the hardness grew from 82, to 107 (HB) with rising Te content to $0.5 \mathrm{wt}$. \%. However, the findings proved that increasing Te shifted the corrosion potentials to more negatives values.
\end{abstract}

Keywords: Al-Zn-Mg alloys; Grain size; Hardness; corrosion; pitting; passivity

* Corresponding author.

E-mail address: engamh3ma@yahoo.com (A.M. Hosny). Tel:+201066619751 


\section{Introduction}

Recently, Al-Zn-Mg alloys have been comprehensively utilized in structural components of aerospace and automotive industries owing to their higher strength-weight ratio, good machinability, cast-ability and weldability [1-3]. The high strength of $\mathrm{Al}-\mathrm{Zn}-\mathrm{Mg}$ alloys is due to the fine and uniformly distributed precipitates $\eta^{\prime}\left(\mathrm{MgZn}_{2}\right)$ in the matrix. However, satisfactory corrosion resistance is required beside the excellent mechanical properties. Alloying is one of the main methods to improve the comprehensive properties of $\mathrm{Al}-\mathrm{Zn}-\mathrm{Mg}$ alloys [4-9]. Incorporating various alloying elements into Al-matrix can improve the necessary mechanical and corrosion properties $[9,10]$.

The corrosion behavior of $\mathrm{Al}-\mathrm{Zn}-\mathrm{Mg}$ alloys is related to their multi-elements and their distribution in the matrix. These elements may be either in solid solution form or segregated as second-phase particles, intermetallic compounds or inclusions. Both the initiation of attack and the propagation of dissolution depend on local zones where the enrichment of the alloying elements occur [11]. Shi et al [12] investigated the role of $\mathrm{Sc}$ and $\mathrm{Zr}$ on stress corrosion cracking of $\mathrm{Al}-\mathrm{Zn}-\mathrm{Mg}-\mathrm{Cu}$ alloys. It was found that the susceptibility of stress corrosion cracking for $\mathrm{Al}-\mathrm{Zn}-\mathrm{Mg}-\mathrm{Cu}$ alloys declined when $\mathrm{Sc}$ and $\mathrm{Zr}$ contents of increased. Further, the findings indicated that the area of GBPs decreased with increasing of Sc and $\mathrm{Zr}$ contents in the matrix. Liu et al [13]concluded that addition of Sc can suppress the recrystallization, refine the grains and narrow PFZs in the Al-Zn-Mg alloys. The removal of $\mathrm{Cu}$ accelerated the coarsening of precipitates and broadened the PFZs in the Al-Zn-Mg-X alloys. The addition of $\mathrm{Sc}$, as well as the removal of $\mathrm{Cu}$, can decrease the corrosion potential and the corrosion current density of $\mathrm{Al}-\mathrm{Zn}-\mathrm{Mg}-\mathrm{X}$ alloys. The corrosion current density of the Sc alloy is 36 times lower than that of the $\mathrm{Cu}$ alloy. Sadawy and Zohdy [3] investigated the influence of tin on the corrosion properties of $\mathrm{Al}-\mathrm{Zn}-\mathrm{Mg}$ in sea water. The outcomes illustrated that the corrosion rate increased with the increase of tin contents. Xiong et al [14] examined the impact of tellurium on the $\mathrm{Al}-\mathrm{Zn}$-In sacrificial anode. The outcomes have assured that addition of Te as the alloying element, the $\mathrm{Al}-\mathrm{Zn}-\mathrm{In}$ anode exhibited lower harmful impurity content of $\mathrm{Fe}$ and $\mathrm{Si}$, while an inhibition of self-corrosion and higher current efficiency were obtained. The corrosion of the Al-Zn-In anode with the addition of Te initiated at the $\mathrm{Zn}$ and Te enriched hemispherical segregation in grain boundaries and interdendritic zones.

In the present investigation, the microstructure, mechanical and corrosion properties of as-cast Al$5 \% \mathrm{Wt} . \mathrm{Zn}-2.5 \% \mathrm{Wt}$. Mg alloy with addition of different contents of Te in 3.5\%wt. $\mathrm{NaCl}$ solution was investigated. The effect of Te on the micro-galvanic effect and localized corrosion evolution of $\mathrm{Al}-\mathrm{Zn}$ $\mathrm{Mg}$ alloys are discussed.

\section{Materials and Methods}

\subsection{Materials}

The present study was performed using Al-Zn-Mg-xTe alloys with ( $\mathrm{x}=0,0.625,0.125,0.25$, and 0.5). The alloys were prepared using high purity $\mathrm{Al}, \mathrm{Zn}, \mathrm{Mg}$ and Te. A measured weight of $\mathrm{Al}$ was placed into a graphite crucible and melted at $850^{\circ} \mathrm{C}$. The melt was thoroughly skimmed and then the measured amount of Te was added and mechanically stirred for $3 \mathrm{~min}$. The molten alloy was poured into stainless steel mold of dimensions $(200 \times 50 \times 20 \mathrm{~mm})$ and then cooled naturally to room temperature. Schematic operational sequence during melt is shown in Fig. 1. The fabricated alloys have been analyzed by XRF as shown in Table 1 . The as-cast alloys were cut into $50 \mathrm{~mm} \times 10 \mathrm{~mm} \times$ $10 \mathrm{~mm}$ for different tests. 
Table 1: Chemical compositions (wt. \%) of Al-Zn-Mg-xTe alloys.

\begin{tabular}{|c|c|c|c|c|c|c|c|}
\hline & \multicolumn{7}{|c|}{ Elementals $(w t . \%)$} \\
\hline Samples & Zn & Mg & Te & Fe & Ni & Si & Al \\
\hline S1 & 5.17 & 2.43 & -- & $\leq \mathbf{0 . 0 1 7}$ & $\leq \mathbf{0 . 0 1 8}$ & $\leq \mathbf{0 . 0 1 2}$ & Bal. \\
\hline S2 & 5.44 & 2.43 & $\mathbf{0 . 0 6 2 8}$ & $\leq \mathbf{0 . 0 3 2}$ & $\leq \mathbf{0 . 0 1 6}$ & $\leq \mathbf{0 . 0 1 8}$ & Bal. \\
\hline S3 & $\mathbf{5 . 5 2}$ & $\mathbf{2 . 3 2}$ & $\mathbf{0 . 1 2 7 0}$ & $\leq \mathbf{0 . 0 1 8}$ & $\leq \mathbf{0 . 0 1 3}$ & $\leq \mathbf{0 . 0 2 8}$ & Bal. \\
\hline S4 & $\mathbf{5 . 3 2}$ & $\mathbf{2 . 5 2}$ & $\mathbf{0 . 2 4 5 0}$ & $\leq \mathbf{0 . 0 3 2}$ & $\leq \mathbf{0 . 0 2 4}$ & $\leq \mathbf{0 . 0 1 6}$ & Bal. \\
\hline S5 & $\mathbf{5 . 5 0}$ & $\mathbf{2 . 5 1}$ & $\mathbf{0 . 5 0 6 0}$ & $\leq \mathbf{0 . 0 5 4}$ & $\leq \mathbf{0 . 0 2 2}$ & $\leq \mathbf{0 . 0 2 5}$ & Bal. \\
\hline
\end{tabular}

\subsection{Electrochemical techniques}

Electrochemical measurements were performed using Potentiostat/Galvanostat (EG\&G model 273) controlled by a PC and an electrochemical cell with a three-electrode arrangement. The potential measurements are recorded with respect to $\mathrm{Ag} / \mathrm{AgCl}$ reference electrode. A platinum sheet was used as a counter electrode. The measurements were performed under the atmosphere and room temperature in $3.5 \%$ wt. $\mathrm{NaCl}$ solution.

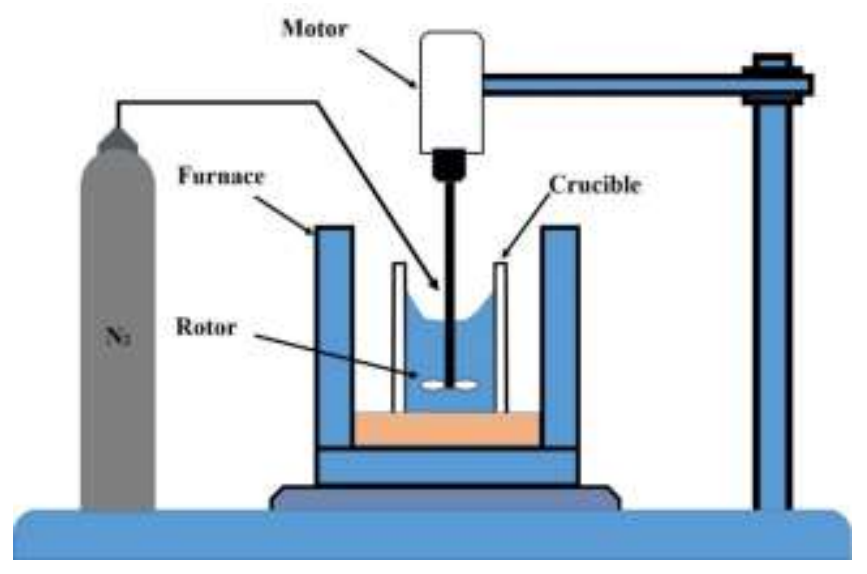

Fig. 1. Schematic operational sequence during melt.

The open-circuit potential (OCP) was recorded for 21 days. The anodic and cathodic polarization curves were recorded by sweeping the potential at a scan rate of $0.5 \mathrm{mV} / \mathrm{s}$ and exposed surface area of $1.0 \mathrm{~cm}^{2}$. Cyclic polarization measurements were carried out by scanning the potential in the forward direction from $-100 \mathrm{mV}$ vs. corrosion potential $\left(\mathrm{E}^{\mathrm{corr}}\right)$ towards the anodic direction at a scan rate of 1.0 $\mathrm{mV} / \mathrm{s}$. The potential scan was reversed in the backward direction when the anodic current density reached a value of $0.10 \mathrm{~A} / \mathrm{cm}^{2}$. All corrosion experiments were performed in $3.5 \mathrm{wt} \% \mathrm{NaCl}$ solution as electrolyte. The solutions were prepared from analytical grade and chemically pure reagents using deionized water. 


\subsection{Surfaces characterization}

For microstructure examinations, samples of dimensions $(50 \times 10 \times 10)$ were cut from each ingot using disc cutter and mechanically polished using SiC emery paper of grades 400-1200. All samples were etched using a Keller solution of $25 \mathrm{~mL} \mathrm{HNO}_{3}, 15 \mathrm{~mL} \mathrm{HCl}, 10 \mathrm{~mL} \mathrm{HF}$ and $150 \mathrm{~mL}$ distilled $\mathrm{H}_{2} \mathrm{O}$. The metallographic study was carried out using Olympus optical microscope. Further, a scanning electron microscope (SEM, JEOL JSM-5800LV) was used for microstructure and morphologies of the samples after corrosion.

\section{Results and Discussions}

\subsection{Microstructures evolution}

The microstructures of the alloys with different Te content are shown in Fig. 2. Clearly, all alloys show a grains microstructure. The grain size of the alloys as shown in Fig. 3 grows with increasing Te content. It can be noted that the grain size grows by $30.58,66.66,76.86$, and $78.09 \%$ with rising Te content to $0.625,0.125,0.25$, and 0.5 wt. \%, respectively (Fig. 4). The SEM/EDX as shown in Figs. $5 \& 6$ show that the precipitates locate between the grain boundaries and a net workshaped is obtained. The arms of IMPs are declined with increasing Te content showing a reduction in grain size. Similar results were reported elsewhere [15]. Further, the findings show that Te is found freely in the matrix.

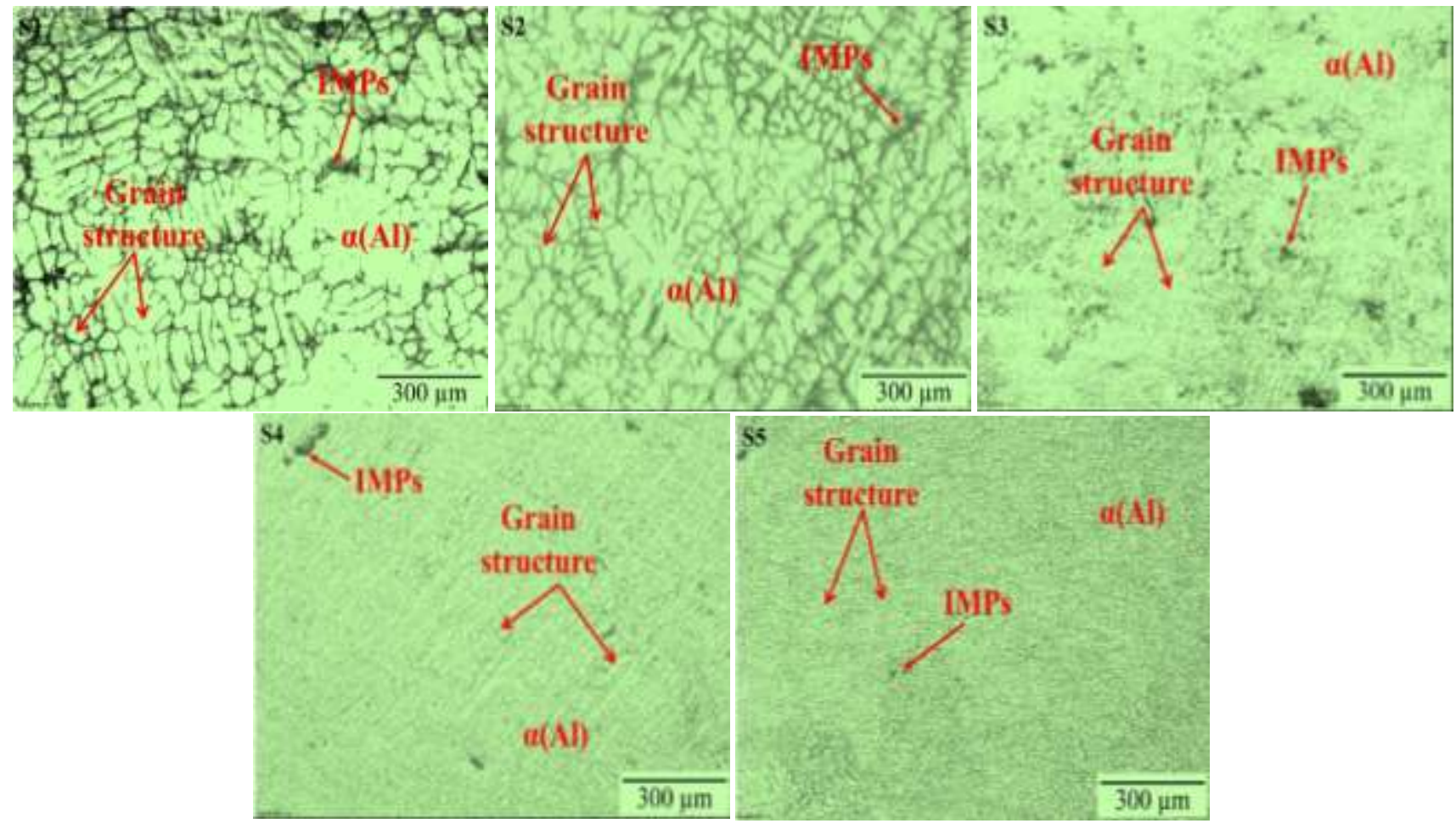

Fig. 2. Optical micrograph of Al-Zn-Mg alloy containing different Te content. 

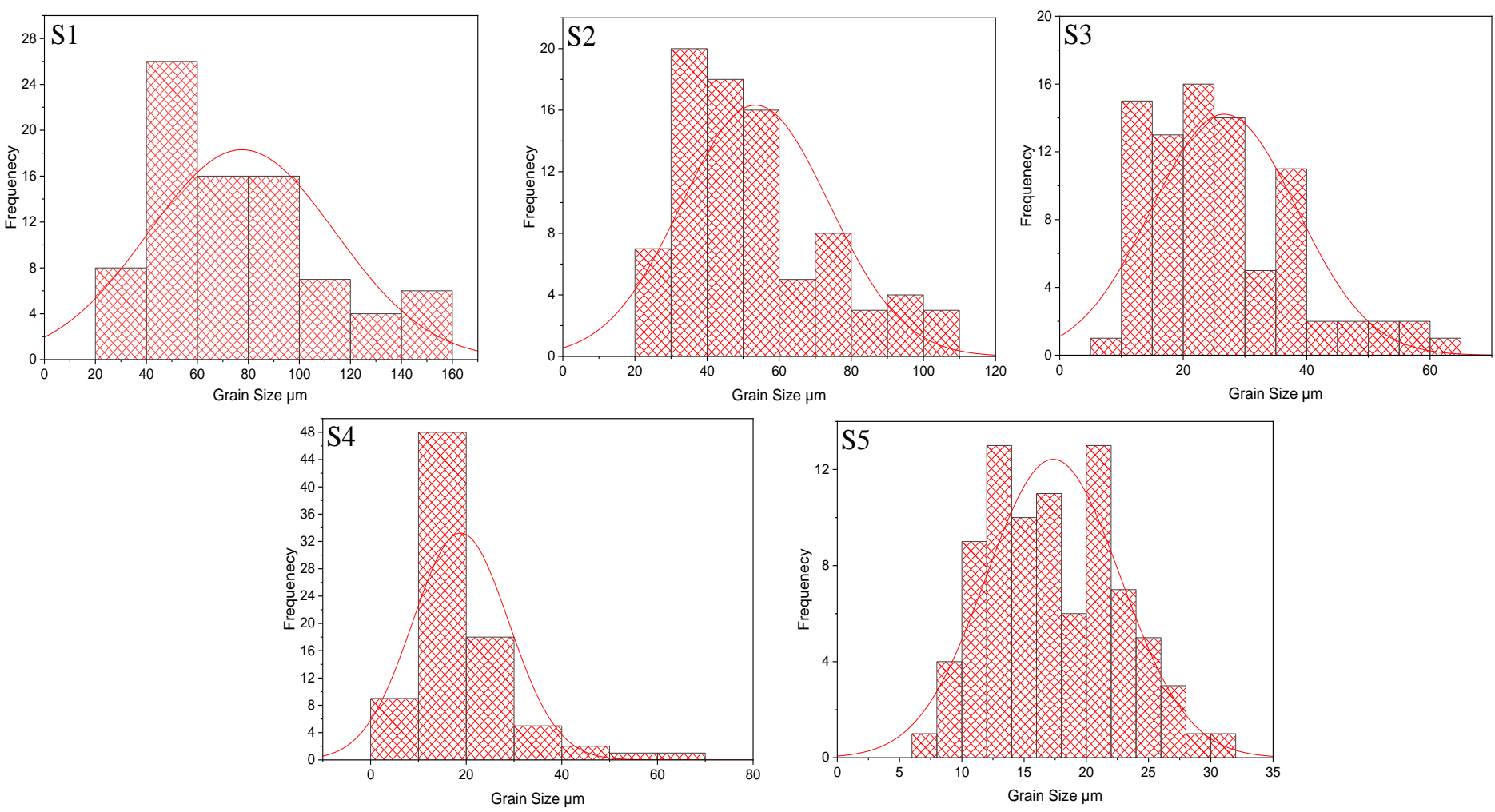

Fig. 3. Histogram of grain size distribution for the investigated samples.

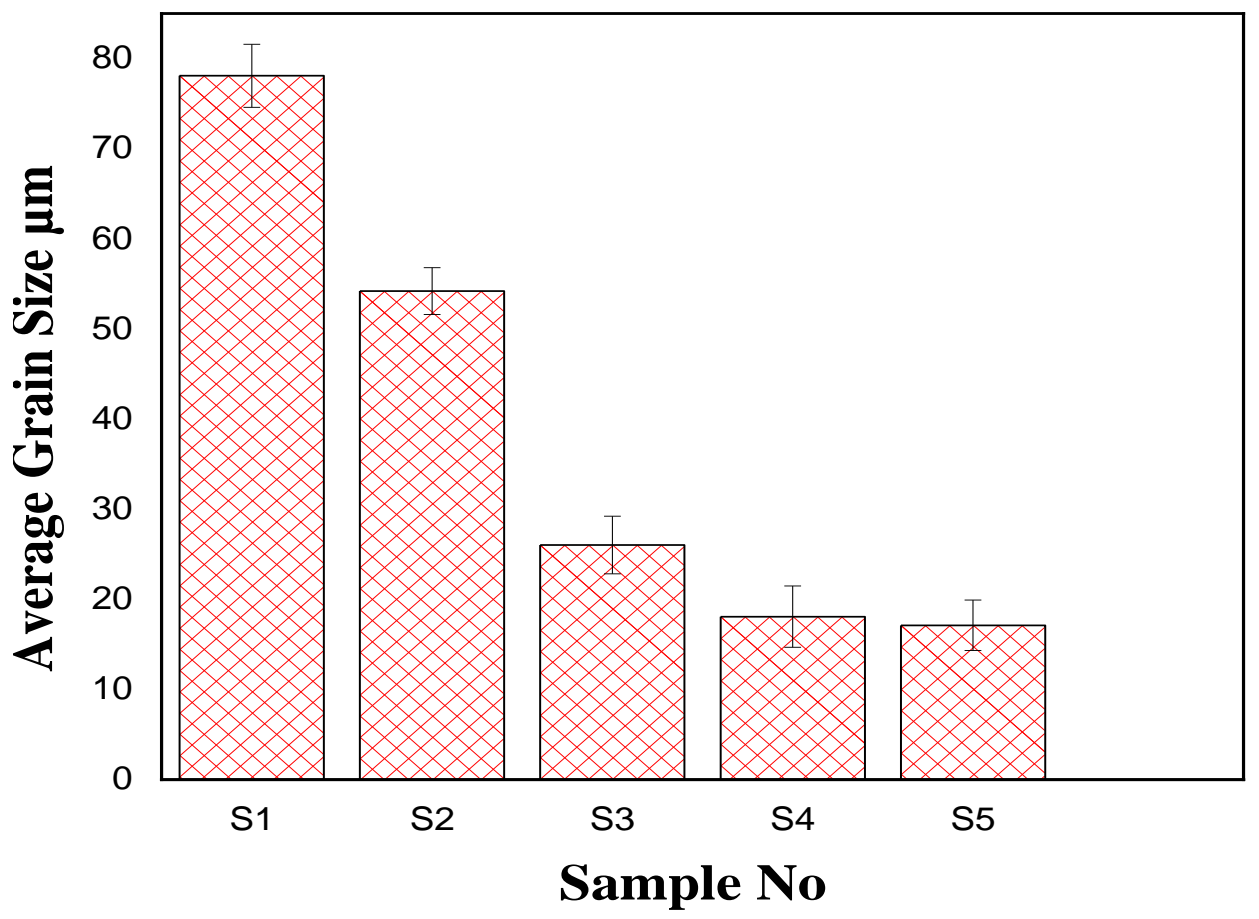


Fig. 4. Average grain size of samples.
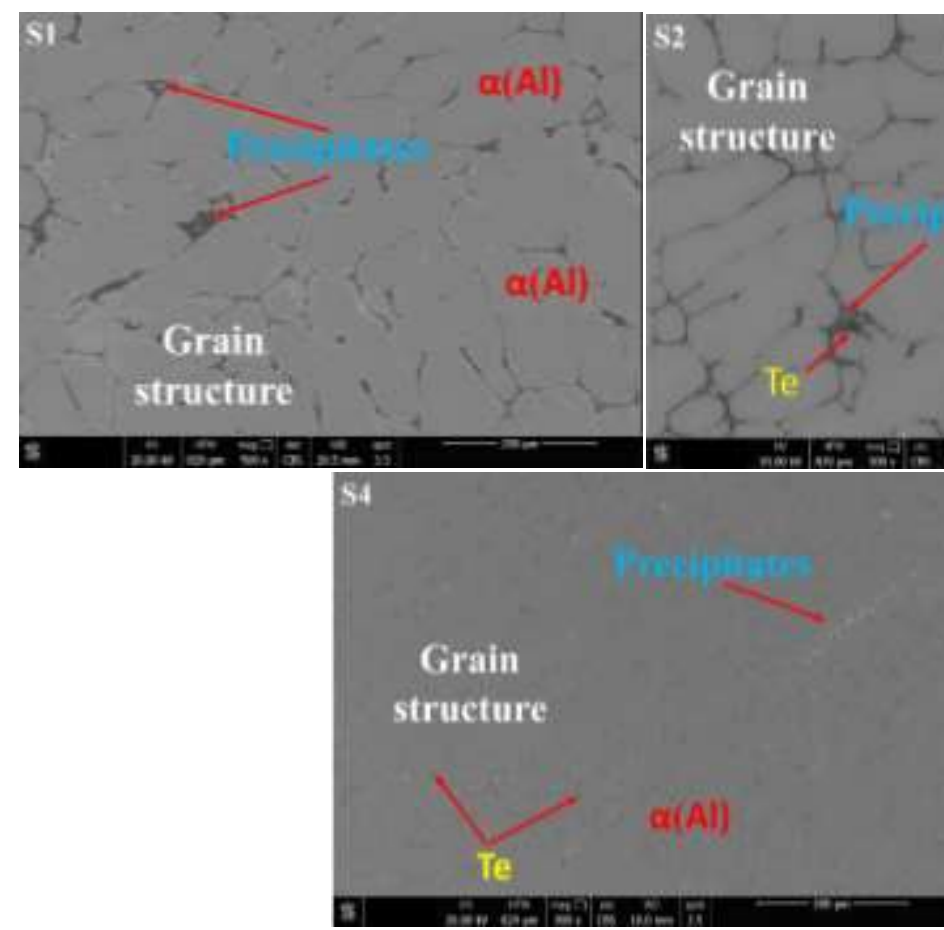

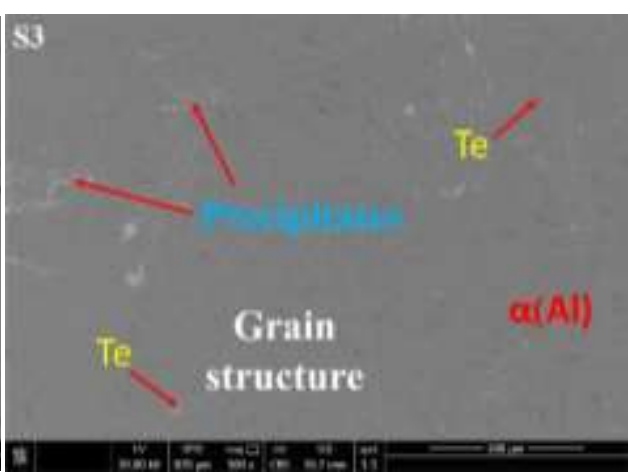

s5

Precipitates

$\mathrm{Te}$

Te

Grain

structure

Fig. 5. SEM images of Al-Zn-Mg alloy samples with and without Te.
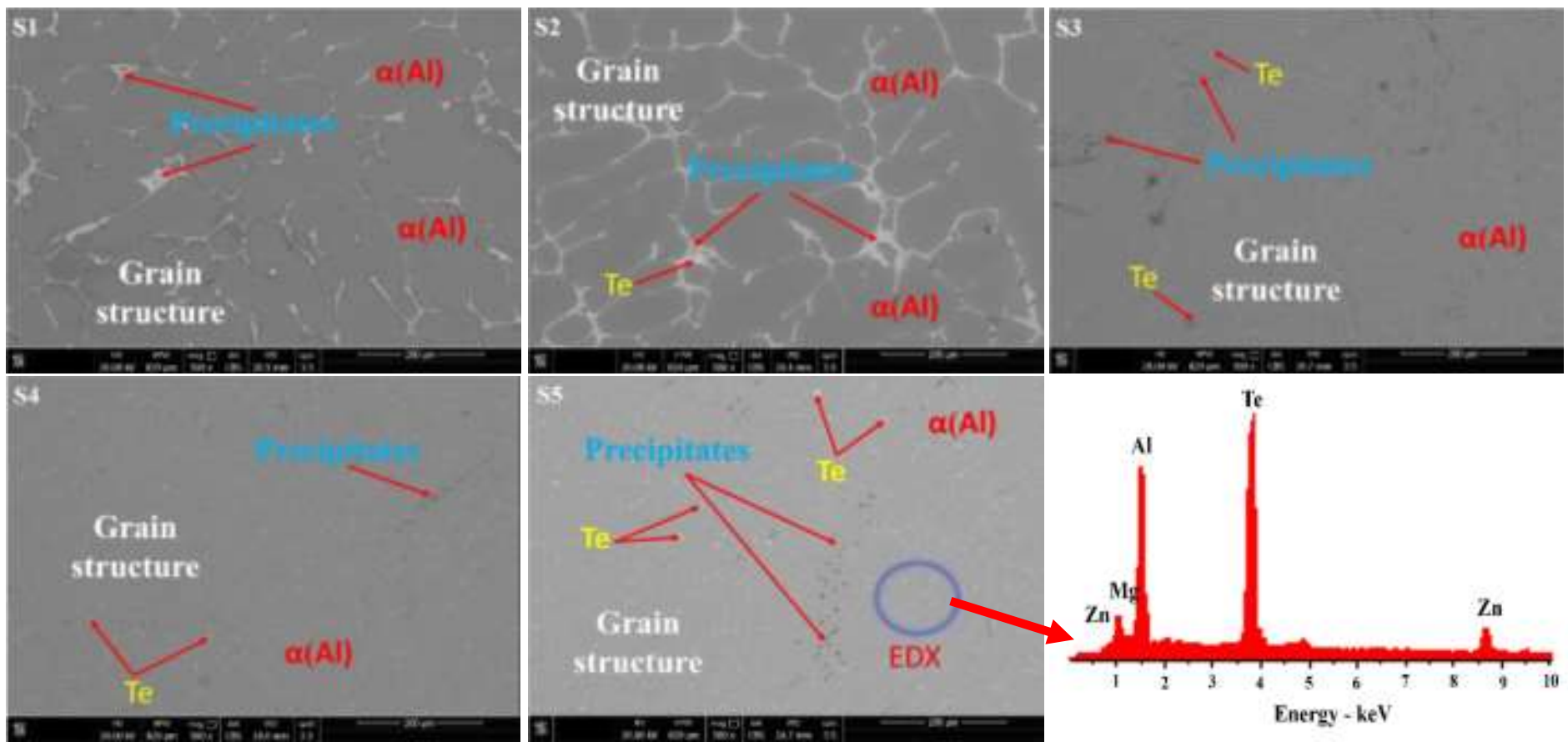
Fig. 6. Backscatter SEM/EDX images of Al-Zn-Mg alloy containing different Te content.

\subsection{Hardness}

The hardness values of Al-Zn-Mg alloy with different values of Te concentration is illustrated in Fig.7. The findings show that all samples containing Te have higher hardness value comparing to the bare $\mathrm{Al}-\mathrm{Zn}-\mathrm{Mg}$ alloy. It is interesting to note that the hardness values grow by 7.31, 14.63, 20.73, and $30.49 \%$; with rising Te concentration to $0.625,0.125,0.25$, and 0.5 wt. $\%$, respectively. This trend according to Abd El Aal \& Sadawy [16] is attributed to refining the grains of $\alpha$-Al. Further incorporating Te into the melt is characterized by a limited solubility in the liquid state and absolute insolubility in the solid state. The structure after solidification, may contain a solid solution or may be segregated as intermetallic compounds, inclusions and second-phase particles[3]. This causes a strain field resulting in an increase in the density of dislocations. Increasing the dislocation reduces the plastic deformation of the alloy[3,17], therefore the hardness increases.

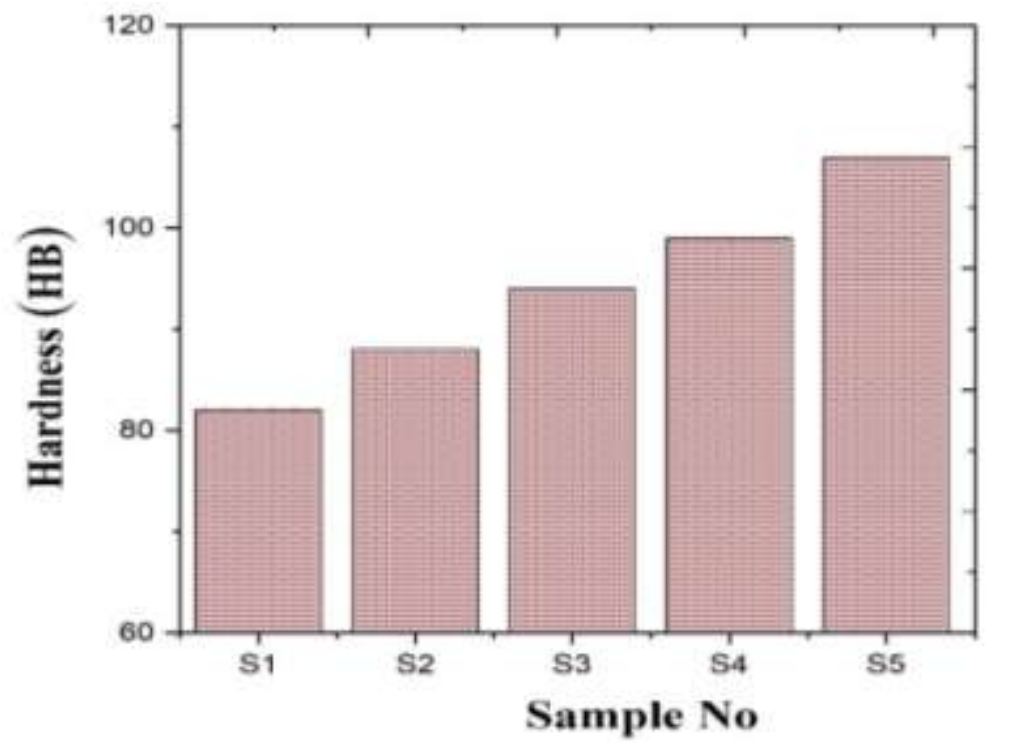

Fig. 7. Hardness values of Al-Zn-Mg alloy samples with and without Te

\subsection{Corrosion behavior}

\subsubsection{Open circuit measurements (OCP)}

The OCP of $\mathrm{Al}-\mathrm{Zn}-\mathrm{Mg}$ with different content of Te in $3.5 \mathrm{wt} . \% \mathrm{NaCl}$ solution is shown in Fig 8 . Clearly, the OCP of all samples have a tendency towards more negative values owing to the catastrophe of the pre-immersion air formed oxide film on alloys surfaces. Additionally, the outcomes illustrate that increment of Te moves the OCP to a more negative value. This means that increasing Te to $0.5 \mathrm{wt} \%$ commendably destroys the $\mathrm{Al}$ lattice and impedes the development of the continuous passive film on the surface of alloys. A similar trend was also obtained by [3] who found that incorporating $\mathrm{Sn}$ into $\mathrm{Al}-\mathrm{Zn}-\mathrm{Mg}$ matrix declined the OCP due to increasing the free $\mathrm{Sn}$ particles that grew the activated the surface.

\subsubsection{Potentiodynamic polarization}

The potentiodynamic polarization curves of $\mathrm{Al}-\mathrm{Zn}-\mathrm{Mg}$ alloy containing different Te content in 3.5 wt. $\% \mathrm{NaCl}$ solution are shown in Fig 9. The cathodic and anodic curves display a traditional shape of $\mathrm{Al}$ alloys in sea water. The cathodic curves represent the reduction of oxygen on the surface of the investigated system according to Eqs.(1) and (2) [14,18]: 


$$
\begin{gathered}
2+2 \mathrm{H}_{2}+4 e^{-}=4 O \mathrm{H}^{-} \\
2 \mathrm{H}_{2}+2 e^{-}=H_{2}+2 O \mathrm{H}^{-}
\end{gathered}
$$

The anodic curves characterize the dissolution of $\mathrm{Al}, \mathrm{Zn}$ and $\mathrm{Mg}$ according to Eqs.(3) - (5) [19]:

$$
\begin{array}{ll}
2 \mathrm{Al}+6 \mathrm{H}_{2} & \rightarrow 2 \mathrm{Al}(\mathrm{OH})_{3} \downarrow+3 \mathrm{H}_{2} \\
\mathrm{Zn}+2 \mathrm{H}_{2} & \rightarrow \mathrm{Zn}(\mathrm{OH})_{2}+\mathrm{H}_{2} \\
\mathrm{Mg}+2 \mathrm{H}_{2} & \rightarrow \mathrm{Mg}(\mathrm{OH})_{2}+\mathrm{H}_{2}
\end{array}
$$

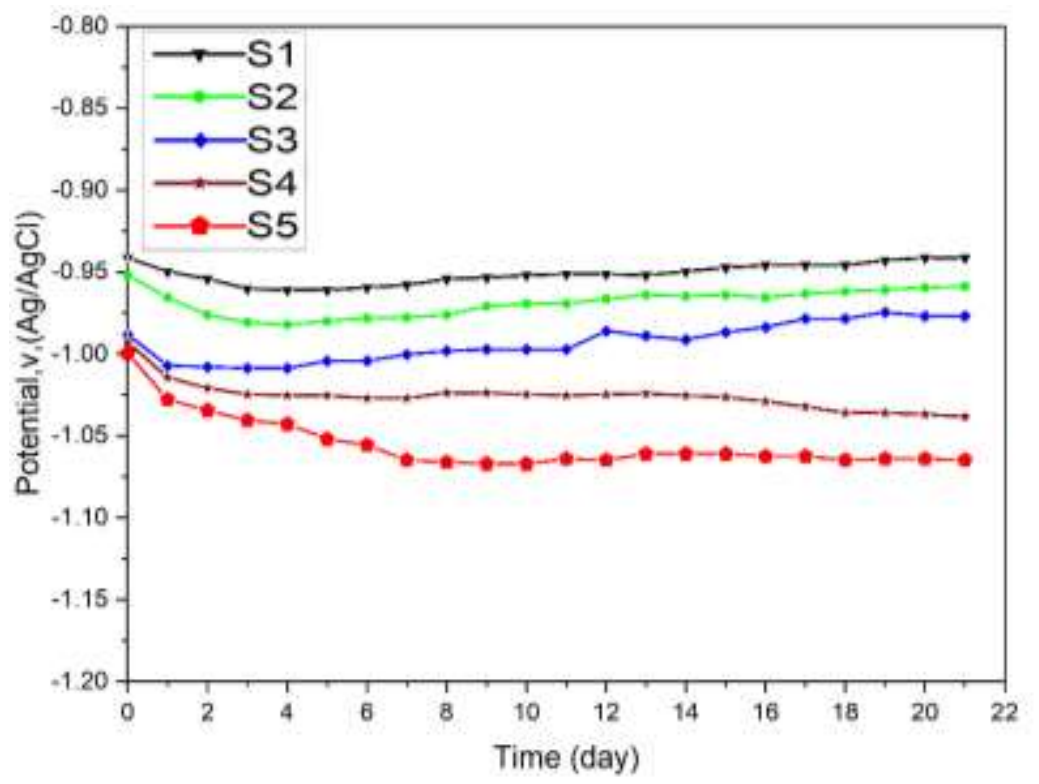

Fig 8. OCP of the investigated alloys in $3.5 \mathrm{wt}$. \% $\mathrm{NaCl}$ solution.

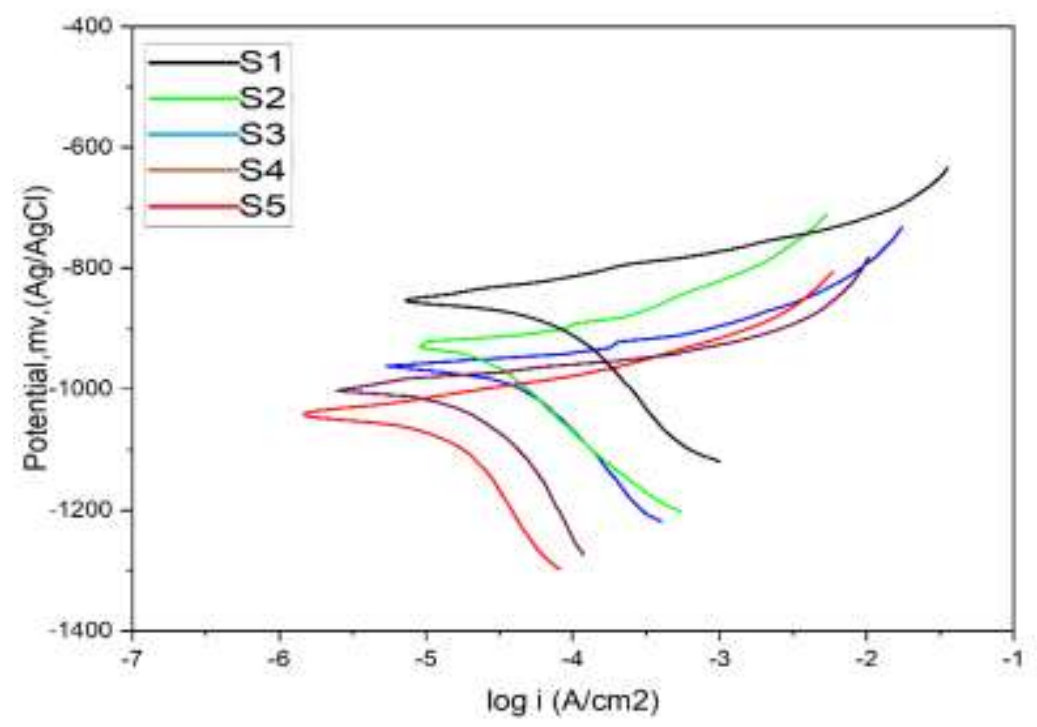


Fig. 9. Tafel plots of Al-Zn-Mg-xTe alloys in 3.5 wt. \% NaCl solution.

The findings show that the cathodic current density decreases with growing Te concentration. The behavior means that Te constrain the hydrogen reaction kinetics. Further Fig 10 depicts that the anodic current density continuously decreases with the growth of Te content, while the corrosion potential $\left(\mathrm{E}^{\mathrm{corr}}\right)$ moves to a more negative value and the corrosion current density $\left(\mathrm{i}^{\text {corr }}\right)$ declines. The electrochemical parameters (corrosion potential $\left(\mathrm{E}^{\mathrm{corr}}\right)$, corrosion current density $\left(\mathrm{i}^{\text {corr }}\right)$, anodic and cathodic slopes ( $\beta \mathrm{a}$ and $\beta \mathrm{c}$ ) were calculated from Tafel plots, and are presented in Table 2.

Table 2: Electrochemical parameters obtained from potentiodynamic polarization

\begin{tabular}{|c|c|c|c|c|c|}
\hline $\begin{array}{c}\text { Sample } \\
\text { (No) }\end{array}$ & $\begin{array}{l}\mathbf{E}^{\mathrm{corr}} \\
(\mathrm{mV})\end{array}$ & $\begin{array}{c}\mathbf{i}^{\text {corr }} \\
\left(\mathbf{A} / \mathrm{cm}^{2}\right)\end{array}$ & $\begin{array}{l}\text { Corrosion rate } \\
\quad(\mathrm{mm} / \mathrm{y})\end{array}$ & $\begin{array}{c}\boldsymbol{\beta}_{\mathrm{c}} \\
(\mathrm{mV} / \mathrm{dec})\end{array}$ & $\begin{array}{c}\boldsymbol{\beta}_{\mathrm{a}} \\
(\mathbf{m V} / \mathbf{d e c})\end{array}$ \\
\hline S1 & $-853 \pm 35.61$ & $(27.54 \pm 1.186) \times 10^{-6}$ & $0.300 \pm 0.016$ & $120.06 \pm 5.211$ & $233.13 \pm 9.32$ \\
\hline $\mathbf{S 2}$ & $-937 \pm 37.71$ & $(8.51 \pm 0.372) \times 10^{-6}$ & $0.093 \pm 0.0045$ & $120.73 \pm 4.853$ & $237.75 \pm 10.33$ \\
\hline S3 & $-970 \pm 28.81$ & $(5.50 \pm 0.163) \times 10^{-6}$ & $0.059 \pm 0.0034$ & $121.08 \pm 5.421$ & $242.65 \pm 10.41$ \\
\hline S4 & $-1000 \pm 40.92$ & $(2.57 \pm 0.077) \times 10^{-6}$ & $0.028 \pm 0.0045$ & $121.87 \pm 5.398$ & $248.78 \pm 11.47$ \\
\hline S5 & $-1045 \pm 42.91$ & $(1.70 \pm 0.051) \times 10^{-6}$ & $0.018 \pm 0.0001$ & $122.05 \pm 5.287$ & $250.07 \pm 11.39$ \\
\hline
\end{tabular}

measurements for $\mathrm{Al}-\mathrm{Zn}-\mathrm{Mg}-\mathrm{xTe}$ alloys in $3.5 \mathrm{wt}$. \% $\mathrm{NaCl}$ solution.

Fig. 10.

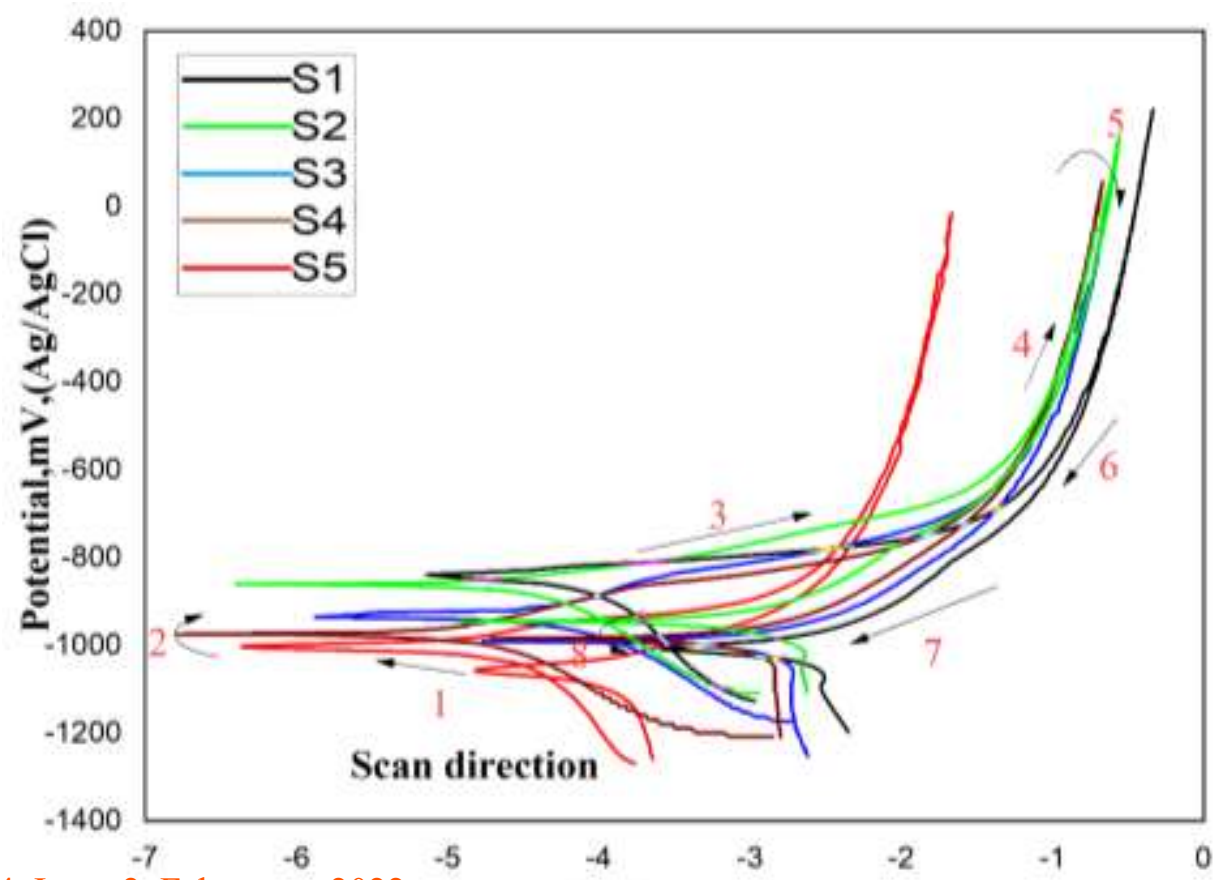




\section{polarization plots of $\mathrm{Al}-\mathrm{Zn}-\mathrm{Mg}-\mathrm{xTe}$ alloys in $3.5 \mathrm{wt}$. \% $\mathrm{NaCl}$ solution.}

The passive stability was examined by cyclic polarization tests (Fig. 10). Commonly, the curves show active, passive and trans-passive regions. However, the range of the passive zone reduces with the increment of Te content. This proposes that Te forms imperfections in the passive layer. Further, Te deteriorate the passive film by breaking its continuity [14]. Table 3 displays the values of the parameters associated to cyclic polarization curves for all samples in $3.5 \mathrm{wt} \% \mathrm{NaCl}$ solution solution. It is clear that the passivation zone of $\mathrm{S} 1$ is about $-788 \mathrm{mV}$, which is higher than all samples. This may be due to denser protective physical barrier. On the other hand, the passivation zone is declined to $790,814,714$, and $815 \mathrm{mV}$ with increasing Te content to $0.625,0.125,0.25$, and $0.5 \mathrm{wt}$. $\%$, respectively and are presented in Table 3. Fig.11 shows the corrosion products formed on the surface of the alloys after cyclic polarization tests. It is obvious that a heavily corrosion products are obtained on the surfaces and covered all surfaces. However, S1 exhibits more dense corrosion products comparing to other samples.

\begin{tabular}{|c|c|c|c|c|c|}
\hline Sample & $\begin{array}{l}\mathbf{E}_{\text {pit }} \\
(\mathbf{m V})\end{array}$ & $\begin{array}{c}\mathbf{i}_{\text {pit }} \\
\left(\mathbf{A} \cdot \mathrm{cm}^{-2}\right)\end{array}$ & $\begin{array}{l}\mathbf{E}_{\text {pass }} \\
(\mathbf{m V})\end{array}$ & $\begin{array}{c}\mathbf{i}_{\text {pass }} \\
\left(A \cdot \mathrm{cm}^{-2}\right)\end{array}$ & $\begin{array}{c}\text { Passive zone } \\
(\mathbf{m V})\end{array}$ \\
\hline S1 & $220 \pm 9.12$ & $(21.22 \pm 0.924) \times 10^{-3}$ & $-658 \pm 28.48$ & $57.54 \pm 2.62 \times 10^{-3}$ & $820 \pm 41.69$ \\
\hline S2 & $152 \pm 6.23$ & $(252.93 \pm 9.325) \times 10^{-3}$ & $-638 \pm 31.51$ & $29.51 \pm 1.85 \times 10^{-3}$ & $790 \pm 39.56$ \\
\hline S3 & $84 \pm 4.32$ & $(408.32 \pm 15.42) \times 10^{-3}$ & $-730 \pm 35.66$ & $25.70 \pm 1.94 \times 10^{-3}$ & $745 \pm 38.81$ \\
\hline S4 & $50 \pm 2.28$ & $(213.80 \pm 10.35) \times 10^{-3}$ & $-774 \pm 38.31$ & $3.16 \pm 0.18 \times 10^{-3}$ & $714 \pm 37.52$ \\
\hline S5 & $-23 \pm 0.99$ & $(275.42 \pm 11.46) \times 10^{-3}$ & $-838 \pm 41.62$ & $1.32 \pm 0.01 \times 10^{-3}$ & $655 \pm 31.64$ \\
\hline
\end{tabular}

Table 3: Electrochemical parameters obtained from cyclic polarization measurements for AlZn-Mg-xTe alloys in 3.5 wt. \% $\mathrm{NaCl}$ solution
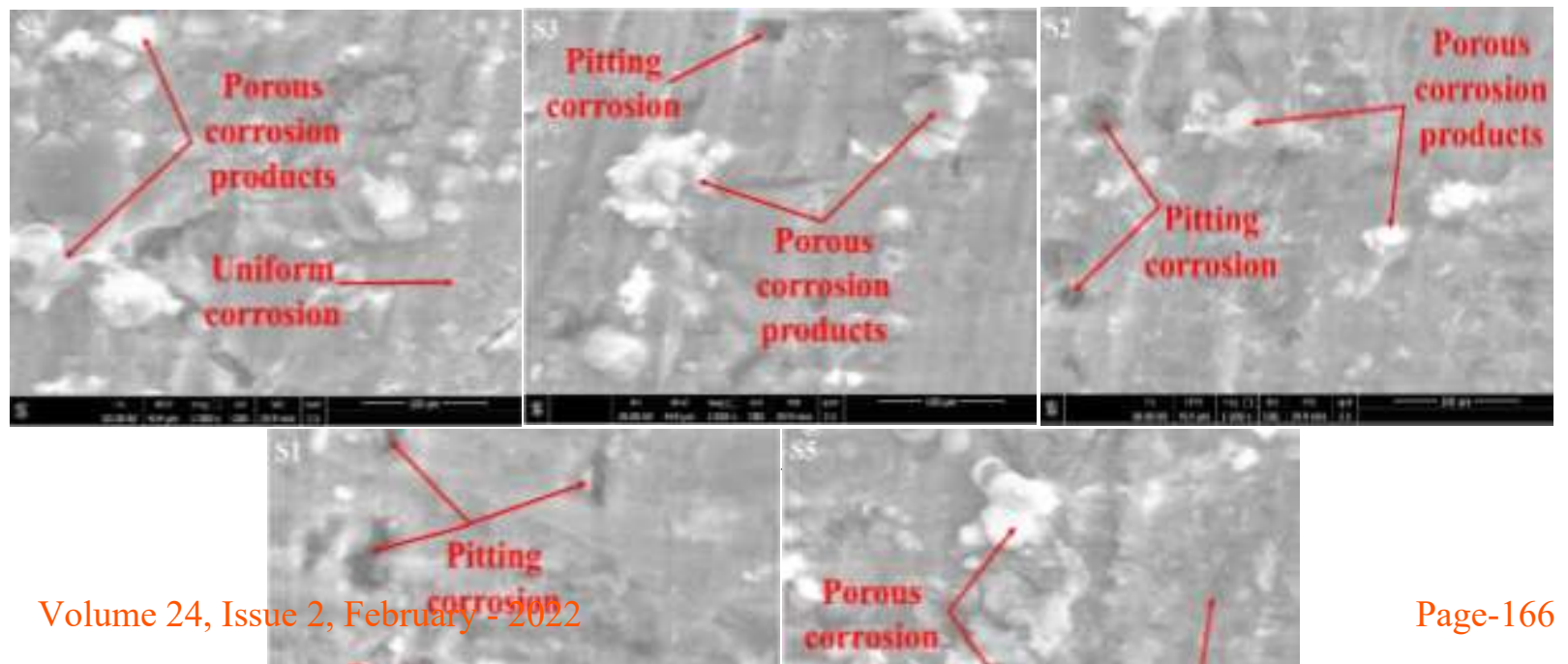
Fig 11. Surface morphologies of samples after cyclic polarization in the $3.5 \mathrm{wt} \% \mathrm{NaCl}$ solution.

\section{Conclusions}

The microstructure, mechanical and corrosion properties of $\mathrm{Al}-\mathrm{Zn}-\mathrm{Mg}$ alloys with different $\mathrm{Te}$ contents have been examined. Depending on the obtained results, the following conclusions can be drawn as follows:

1-The grain size of Al-Zn-Mg alloy is declined with the addition of Te, The size decreased from 30.58 to $78.09 \%$, while the hardness increased from 82, to 107 (HB) with growing Te content to $0.5 \mathrm{wt}$.

2 - Increasing Te value, shifted the corrosion potentials to more negatives values.

3 -Incorporating $\mathrm{Te}$, reduces the amount of intermetallic precipitates in $\alpha$-Al matrix, causing a reduction in the cathodic current density.

4-Increasing Te content to $0.5 \mathrm{wt} \%$ destroyed the continuity of the passive film on the surfaces of AlZn-Mg alloys.

\section{REFERENCES}

[1] M.M. Sadawy, E.A. Eid, Preparation and Electrochemical Behavior of Graphene-Oxide/ZincPhosphate Composite Coatings on as-Cast Al-Zn (5.0 wt.\%)-Mg (2.5 wt.\%) Alloy, Synth. Met. 259 (2020) 116236. https://doi.org/10.1016/j.synthmet.2019.116236.

[2] R. Revel, T. Audichon, S. Gonzalez, Non-aqueous aluminium-air battery based on ionic liquid electrolyte, J. Power Sources. 272 (2014) 415-421. https://doi.org/10.1016/j.jpowsour.2014.08.056.

[3] M.M.Sadawy, K.M.Zohdy, Effect of tin on the corrosion and electrochemical behavior of alzn-mg alloy in sea water, Miner. Met. Mater. Soc. (2014) 383-388.

[4] P. Vijaya Kumar, G. Madhusudhan Reddy, K. Srinivasa Rao, Microstructure and pitting corrosion of armor grade AA7075 aluminum alloy friction stir weld nugget zone - Effect of post weld heat treatment and addition of boron carbide, Def. Technol. 11 (2015) 166-173. https://doi.org/10.1016/j.dt.2015.01.002.

[5] G. Elatharasan, V.S.S. Kumar, Corrosion analysis of friction stir-welded aa 7075 aluminium alloy, Stroj. Vestnik/Journal Mech. Eng. 60 (2014) 29-34. https://doi.org/10.5545/svjme.2012.711.

[6] Corrosion Studies on Friction Welded Dissimilar Aluminum Alloys of AA7075-T6 and AA6061 -T6 | Request PDF, (n.d.). https://www.researchgate.net/publication/285202122_Corrosion_Studies_on_Friction_Welded _Dissimilar_Aluminum_Alloys_of_AA7075-T6_and_AA6061_-T6 (accessed January 19, 2022).

[7] U. Mohammediqbal, V.S. Senthilkumar, Experimental investigation and analysis of microstructure and mechanical properties on twist extrusion forming process of AA7075-T6 aluminium alloy, Int. J. Mech. Mater. Eng. 7 (2012) 24-30. https://www.researchgate.net/publication/288108934_Experimental_investigation_and_analysi s_of_microstructure_and_mechanical_properties_on_twist_extrusion_forming_process_of_A A7075-T6_aluminium_alloy (accessed January 19, 2022).

[8] MASOUD I. M, Effect of Different Cooling Rate After Solution Treatment on the Aging Behavior of 7050 Aluminum Alloys, Int. J. Mech. Eng. 2 (2013) 35-44. http://www.iaset.us/view_archives.php?year=2013\&jtype=2\&id=67\&details=archives. 
[9] M. Chemingui, M. khitouni, G. Mesmacque, A.W. Kolsi, Effect of heat treatment on plasticity of Al-Zn-Mg alloy: Microstructure evolution and mechanical properties, Phys. Procedia. 2 (2009) 1167-1174. https://doi.org/10.1016/j.phpro.2009.11.079.

[10] W. Jurczak, The effect of heat treatment on the structure and corrosion resistance of $\mathrm{Al}-\mathrm{Zn}-\mathrm{Mg}$ alloys, Polish Marit. Res. 15 (2008) 66-71. https://doi.org/10.2478/v10012-007-0099-5.

[11] M.A. Jingling, W. Jiuba, L.I. Gengxin, X. V. Chunhua, The corrosion behaviour of Al-Zn-InMg-Ti alloy in $\mathrm{NaCl}$ solution, Corros. Sci. 52 (2010) 534-539. https://doi.org/10.1016/j.corsci.2009.10.010.

[12] Y. Shi, Q. Pan, M. Li, X. Huang, B. Li, Influence of alloyed Sc and Zr, and heat treatment on microstructures and stress corrosion cracking of Al-Zn-Mg-Cu alloys, Mater. Sci. Eng. A. 621 (2015) 173-181. https://doi.org/10.1016/j.msea.2014.10.058.

[13] L. Liu, Y.Y. Jia, J.T. Jiang, B. Zhang, G.A. Li, W.Z. Shao, L. Zhen, The effect of Cu and Sc on the localized corrosion resistance of Al-Zn-Mg-X alloys, J. Alloys Compd. 799 (2019) 114. https://doi.org/10.1016/j.jallcom.2019.05.189.

[14] W. Xiong, G.T. Qi, X.P. Guo, Z.L. Lu, The Effect of Tellurium on the Al-Zn-In Anode, J. Electrochem. Soc. 158 (2011) C48. https://doi.org/10.1149/1.3528933.

[15] H.A. El Shayeb, F.M. Abd, E. Wahab, S. Zein, E. Abedin, Electrochemical behaviour of Al, $\mathrm{Al}-\mathrm{Sn}, \mathrm{Al}-\mathrm{Zn}$ and $\mathrm{Al}-\mathrm{Zn}-\mathrm{Sn}$ alloys in chloride solutions containing stannous ions, Corros. Sci. 43 (2001) 655-669. www.elsevier.com/locate/corsci.

[16] M.I. Abd El Aal, M.M. Sadawy, Influence of ECAP as grain refinement technique on microstructure evolution, mechanical properties and corrosion behavior of pure aluminum, Trans. Nonferrous Met. Soc. China (English Ed. 25 (2015) 3865-3876. https://doi.org/10.1016/S1003-6326(15)64034-1.

[17] H.A. EL-Fattah, M.A. Metwally, M.M. Sadawy, I. .G.El-Batanony, Influence of SiC Content on Microstructure, Dislocation Density and Mechanical Behavior of $\mathrm{Cu} / \mathrm{SiC}$ Composite, $\mathrm{J}$. Univ. Shanghai Sci. Technol. 24 (2022) 186-200.

[18] H. Yang, X. Li, Y. Wang, L. Gao, J. Li, D. Zhang, T. Lin, Excellent performance of aluminium anode based on dithiothreitol additives for alkaline aluminium/air batteries, J. Power Sources. 452 (2020) 227785. https://doi.org/10.1016/j.jpowsour.2020.227785.

[19] J. Ma, J. Wen, J. Gao, Q. Li, Performance of Al-0.5 Mg-0.02 Ga-0.1 Sn-0.5 Mn as anode for Al-air battery in $\mathrm{NaCl}$ solutions, J. Power Sources. 253 (2014) 419-423. https://doi.org/10.1016/j.jpowsour.2013.12.053. 